\title{
JURNAL POLITIK PROFETIK
}

VOLUME 8 NOMOR 2 DESEMBER 2020

\section{ARTIKEL}

Mengapa Partai Islam Belum Pernah Menang?: Path Dependence Repetition Kekalahan Partai Islam Indonesia Dalam Pemilu Legislatif 1955 Hingga 2019

Agus Riyanto

186-217

Gerakan Syarikat Islam Kembali Ke Khittah Tahun 1905

Gugun Wardiono, Bowo Sugiarto, Ahmad Rofik

218-239

Internationalization Of Islam Rahmatan Lil 'Alamin Through

Pengurus Cabang Istimewa Nahdlatul Ulama (PCINU):

Motivation And Contribution

Andi Purwono

240-257

Dinasti Politik: Basis Politik dan Kepuasan Publik

Wimmy Haliim, Andy Iman Hakim

Analisis Biopolitik Dan Kontrol Populasi Penduduk Melalui

Program Keluarga Berencana Di Kota Samarinda

M. Najeri Al Syahrin, Mochamad Dziqie Aulia Al Farauqi, Sri Wahyuni Jamal

274-295

Pemanfaatan Modal Sosial Appi Dalam Pemilihan

Kepala Daerah Di Kota Makassar

Hidayat Doe, Muhammad, Sukri, Ariana

296-312

RESENSI BUKU

Oligarki Di Indonesia: Relasi Kapital Yang Dominan

Sunardi

313-317 


\title{
ANALISIS BIOPOLITIK DAN KONTROL POPULASI PENDUDUK MELALUI PROGRAM KELUARGA BERENCANA DI KOTA SAMARINDA
}

\author{
M. Najeri Al Syahrin ${ }^{1}$, Mochamad Dziqie Aulia Al Farauqi ${ }^{2}$, Sri Wahyuni Jamal ${ }^{3}$ \\ Dosen Ilmu Pemerintahan Universitas Lambung Mangkurat ${ }^{1}$ \\ Dosen Ilmu Hubungan Internasional Universitas Muhammadiyah Kalimantan Timur ${ }^{2}$ \\ Dosen Manajemen Universitas Muhammadiyah Kalimantan Timur ${ }^{3}$ \\ Email: najeri.syahrin@ulm.ac.id ${ }^{1}$, mdaa343@umkt.ac.id², \\ swj579@umkt.ac.id ${ }^{3}$
}

\begin{abstract}
Abstrak
Perkembangan populasi penduduk semakin meningkat secara drastis dalam beberapa tahun terakhir, termasuk juga di kota Samarinda, Kalimantan Timur. Ironisnya, jumlah populasi penduduk yang besar tersebut tidak didukung oleh kualitas hidup dan ketersediaan pangan yang memadai. Permasalahan ini menjadikan pemerintah berupaya untuk mendisiplinkan masyarakat dengan cara nir-kekerasan melalui program Keluarga Berencana (KB). Upaya tersebut terwujud dalam mekanisme kebijakan yang menghubungkan antara perkembangan ilmu pengetahuan dalam bidang kesehatan (program KB) dengan aspek sosial secara politis (biopolitik). Upaya pendisiplinan jumlah populasi penduduk yang dilakukan tersebut bukan hanya karena kepentingan kesehatan saja tetapi juga merupakan kebijakan strategis politik. Tujuan dari penelitian ini adalah memberikan analisis dan menjelaskan bahwa pemerintah menjalankan program KB tidak hanya karena permasalahan kesehatan saja tetapi juga sebagai upaya politik untuk melakukan kontrol populasi penduduk (biopolitik). Penelitian ini menggunakan metode kualitatif dengan menggunakan studi pustaka berbasis dokumen dan wawancara dengan subjek terbatas. Di Samarinda, Negara telah melakukan sinergi kebijakan dan anggaran baik di level pemerintah pusat, pemerintah provinsi dan pemerintah kota dalam bentuk kegiatan dan program pendirian kampung $K B$, penurunan angka kelahiran (total fertility rate), peningkatan jumlah angka pemakaian alat/obat kontrasepsi (contraceptive prevalence rate), kerja sama dan koordinasi dengan BKKBN Provinsi dan Dinas Kesehatan, serta meningkatkan kualitas dan kuantitas PLKB/PKB, pelibatan Babinsa Koramil serta penyedian kegiatan program KB gratis. Keseluruhan upaya tersebut merupakan kebijakan biopolitik untuk melakukan kontrol terhadap populasi penduduk. Jika terjadi ketidakseimbangan antara jumlah populasi penduduk dengan beban dan kemampuan negara, maka secara perlahan negara akan menuju pusaran permasalahan sosial yang kompleks.
\end{abstract}

\section{Kata Kunci:}

Biopolitik, Program Keluarga Berencana, Kontrol Populasi, Samarinda

\begin{abstract}
The population has increased dramatically in recent years, including in Samarinda, East Kalimantan. Ironically, the large population is not supported by the quality of life. This problem makes the government strive to discipline the community in a nonviolent
\end{abstract}


way through the Keluarga Berencana $(K B)$ program. These efforts are manifested in the policy mechanism which links the health science and political social aspects (biopolitics). The effort to control the population is not only because of the health policy's interest but also as a political-strategic policy. The purpose of this study is providing an analysis of Keluarga Berencana program as the strategy to overcome the health issues and as the implementation of biopolitics. This research uses quantitative methods using document-based literature studies and interviews. In Samarinda, the government has synergized policies and budgets at all level of government, in the form of activities and programs for the establishment of Keluarga Berencana village, decreased the fertility rate, increased number of contraceptive prevalence rate, cooperation and coordination with the Provincial BKKBN and the ministry of health, as well as increasing the quality and quantity of PLKB/PKB, involving Babinsa Koramil and providing free Keluarga Berencana program activities. These activities is an implementation of biopolitical policy to control the population. If there is an imbalance between the population and the burden and ability of the state, then the country will slowly go to the more complex social problems.

\section{Keywords:}

Biopolitics, Keluarga Berencana Program, Population Control, Samarinda

\section{Pendahuluan}

Perkembangan populasi penduduk meningkat secara drastis dalam beberapa tahun terakhir. Data dari UN DESA World Population Prospects menyatakan bahwa penduduk dunia kini berjumlah sekitar 7,3 miliar jiwa. Dalam beberapa tahun ke depan diprediksi penduduk dunia akan mencapai angka 8,5 miliar jiwa pada tahun 2030 serta akan semakin meningkat menjadi 9,7 miliar jiwa pada tahun 2050. ${ }^{1}$ Di Indonesia, problematika populasi penduduk juga dirasakan bersama dengan menurunnya kualitas hidup yang rendah dan keterbatasan pangan nasional. Dengan jumlah penduduk sebanyak 258.704.900 juta jiwa, Indonesia menempati urutan ke-4 negara berpenduduk terbesar di seluruh dunia. ${ }^{2}$ Provinsi Kalimantan Timur, dengan ibukotanya Samarinda merupakan salah satu kota yang memiliki populasi yang tinggi khususnya di wilayah Kalimantan. Tahun 2010, penduduk Samarinda berjumlah sekitar 727.500 jiwa yang kemudian meningkat tahun 2015 menjadi 812.597 jiwa. Laju pertumbuhan populasi per tahun Samarinda juga tergolong tinggi yakni sebesar 1956 jiwa per tahun. ${ }^{3}$

\footnotetext{
1 United Nations, "World Population Projected to Reach 9.7 billion by 2050" dalam http://www .un.org/en/development/desa/news/population/2015-report.html diakses 19 Agustus 2020.

2 Badan Pusat Statistik, Statistik Indonesia 2017 (Jakarta: BPS - Statistik Indonesia, 2017), h. 45-47.

3 Badan Pusat Statistik Kota Samarinda, "Jumlah Penduduk dan Laju Pertumbuhan Penduduk Menurut Kecamatan di Kota Samarinda 2010-2015” dalam https://samarindakota.bps.go.id/
} 
Ironisnya, jumlah populasi penduduk yang besar tersebut tidak didukung oleh kualitas hidup dan ketersediaan pangan yang memadai. Oleh karena itu, pengendalian populasi pertumbuhan penduduk dirasakan semakin mendesak. Dengan ketersediaan sumber daya alam yang terbatas tentu pertambahan penduduk yang besar akan mengancam stabilitas pangan dan politik. Permasalahan ini menjadikan negara berupaya untuk mendisiplinkan masyarakat dengan cara nir-kekerasan. Bagi negara, masyarakat perlu didisiplinkan melalui seperangkat metode pengawasan sehingga dapat patuh terhadap kebijakan negara. ${ }^{4}$ Negara mencoba membuat mekanisme yang menghubungkan antara perkembangan ilmu pengetahuan dalam bidang kesehatan yakni melalui program Keluarga Berencana (KB) dengan aspek sosial secara politis. Pemerintah berupaya untuk memproduksi teknologi untuk mengatur masyarakat untuk selaras dengan kebijakan pemerintah. ${ }^{5}$ Secara garis besar, upaya pendisiplinan jumlah populasi penduduk yang dilakukan tersebut bukan hanya karena kepentingan kesehatan saja tetapi juga serangkaian kebijakan strategis politik. Strategi ini merupakan upaya kontrol populasi yang penting, dalam merekonstruksi masyarakat untuk memisahkan kehidupan pribadinya (permasalahan reproduksi) menjadi permasalahan sosial (overpopulasi). ${ }^{6}$

Di Indonesia, termasuk juga di Samarinda, upaya pemerintah untuk melakukan kontrol populasi tersebut dilakukan sejak tahun 1970 melalui program KB. Sejak dilaksanakan, program KB dinilai efektif mampu menurunkan angka kelahiran penduduk. Dalam konteks tersebut, analisis penelitian akan dilakukan. Bagaimana analisis biopolitik dalam program KB di Samarinda menjadi dasar pertanyaan penelitian. Penelitian ini pada dasarnya tidak menolak kebijakan program KB tetapi ingin melakukan analisis secara lebih mendalam dengan pendekatan ilmu politik bahwa kebijakan program KB di Indonesia sebenarnya bukan hanya kebijakan yang terpusat dalam bidang kesehatan saja, namun lebih dominan merupakan kebijakan politik.

\footnotetext{
statictable/2016/10/19/13/jumlah-penduduk-dan-lajupertumbuhan-penduduk-menurut-kecamatan-di-kotasamarinda-2010-2014-dan-2015.html. diakses 11 Agustus 2020.

4 Elizabeth A. Povinelli, Mathew Coleman \& Kathryn Yusoff, "An Interview with Elizabeth Povinelli: Geontopower, Biopolitics and the Anthropocene” dalam Theory Culture \& Society, Vol. 34, No. 2-3 (2017), h. 169-185.

${ }^{5}$ Jacob Nilsson \& Sven-Olov Wallenstein (ed.), Foucault, Biopolitics and Governmentality (Stockholm: Huddinge, 2013), h. 17.

${ }^{6}$ Willem Schinkel, "From Zoepolitics to Biopolitics: Citizenship and the Construction of Society" dalam European Journal of Social Theory, Vol. 13, No. 2 (2010), h. 155-172.
} 
Argumen dasarnya, bahwa jika terjadi ketidakseimbangan antara jumlah populasi penduduk dengan beban dan kemampuan negara, maka secara perlahan negara akan menuju pusaran permasalahan sosial yang kompleks.

Secara lebih mendalam, tujuan utama dari penelitian adalah memberikan analisis bahwa pemerintah menjalankan program KB tidak hanya karena permasalahan kesehatan saja tetapi juga sebagai upaya politik dalam melakukan kontrol populasi penduduk (biopolitik).

\section{Metode Penelitian}

Penelitian ini merupakan jenis penelitian deskriptif dengan metode kualitatif, yaitu metode untuk mengeksplorasi dan memahami makna oleh sejumlah individu atau kelompok yang berasal dari masalah sosial kemanusiaan. ${ }^{7}$ Secara sederhana, penelitian kualitatif dapat dinyatakan dengan meneliti informan, sebagai subjek penelitian, dalam lingkungan kesehariannya, bersifat alamiah. dinamis, dan dengan subjek terbatas. Selain itu, penelitian ini mengutamakan data primer, observasi dan interpretasi diri dalam mengumpulkan data sehingga kesimpulan penelitian bersifat subjektif. ${ }^{8}$ Lokasi penelitian dilaksanakan di Samarinda dan secara spesifik di lakukan di 5 Kecamatan utama yaitu, Samarinda Kota, Ilir, Ulu, Seberang dan Utara.

Subjek penelitian ini adalah institusi pemerintah yang terdiri dari Dinas Kesehatan, Badan Kependudukan dan Keluarga Berencana (BKKBN) Provinsi Kalimantan Timur dan Kota Samarinda, serta Puskesmas di 5 Kecamatan Kota Samarinda yang menjadi instrumen pemerintah dalam menjalankan program KB. Subjek penelitian ini dipilih dan ditentukan dengan purposive sampling seperti stakeholders yang berada di institusi kesehatan tersebut. Desain penelitian dilakukan dengan model interaktif dari Huberman \& Miles. ${ }^{9}$ Model ini terdiri dari dua tahapan utama, yaitu; Pertama, tahapan pengumpulan data. Secara terperinci tahapan pengumpulan data dalam metode penelitian ini dilakukan dengan dua cara, yaitu: studi pustaka berbasis dokumen dan wawancara. Kedua, tahapan analisa data. Proses analisa data terdiri dari tiga bagian, pertama reduksi data, kedua penyajian data dan ketiga

\footnotetext{
${ }^{7}$ John Creswell, Research Design: Qualitative, Quantitative and Mixed Methods Approaches (California: Sage Publications, 2013), h. 7-13.

${ }^{8}$ Muhammad Idrus, Metode Penelitian Ilmu Sosial (Yogyakarta: Erlangga, 2009). h. 29

${ }^{9}$ Ibid., h. 30-32.
} 
penarikan kesimpulan serta verifikasi. Selanjutnya adalah tahapan analisis data. Tahapan analisis data dilakukan berdasarkan tiga tahapan utama yaitu reduksi data, penyajian data, serta penarikan kesimpulan.

\section{Biopolitik: Strategi Pendisiplinan dan Pengontrolan}

Biopolitik atau biopower, seperti yang dirangkum Foucault adalah tentang penaklukan tubuh dan kontrol populasi. Ini adalah bentuk kekuatan yang menyebar melalui masyarakat sebagai alat yang efektif dalam hubungan kekuasaan untuk normalisasi tindakan sosial dan perilaku populasi. Teori biopolitik merupakan kerangka analisis yang menghubungkan antara biologi dan politik. Biopolitik melihat masyarakat sebagai sebuah objek kalkulasi politik dan mekanisme untuk didisiplinkan dengan berbagai instrumen kekuasaan dan mekanisme disiplin dengan motif untuk menjamin keamanan negara. ${ }^{10}$

Di bawah skenario ini, kekuatan negara dan otoritas lain yang berupa Kampung KB dan seluruh strukturnya telah tersebar dan semakin menginvasi berbagai bidang sosial sebagai cara mewujudkan tujuan mengelola dan mengatur kehidupan penduduk di seluruh Samarinda. Selain memiliki massa jumlah penduduk sebagai target utama dalam pendirian Kampung KB ini, strategi dan taktik biopower juga dimaksudkan untuk meningkatkan kesejahteraan sosial, mental dan fisik warga negara, termasuk usia dan produktivitasnya. Tujuan dari pemerintah untuk mengendalikan dan mengatur kehidupan dengan pendirian Kampung KB yang massif di seluruh wilayah kota adalah upaya kontrol populasi (biopolitik). Dengan demikian, hal tersebut bisa dikategorikan sebagai strategi politik. ${ }^{11}$

Foucault mengklasifikasikan bahwa mekanisme pelaksanaan kontrol kekuasaan (negara dan pemerintah) terhadap kehidupan masyarakat dapat dibagi ke dalam dua bentuk, pertama pendisiplinan tubuh individu dan kedua yakni kontrol aturan (regulasi) terhadap populasi. Bentuk yang pertama, diklasifikan dalam bentuk teknologi pengendalian terhadap tubuh individu (mesin) yang dilakukan secara produktif guna

${ }^{10}$ Michael Dillon \& Luis Lobo-Guerrero, "Biopolitics of Security in the 21st Century: An Introduction" dalam Review of International Studies, Vol. 34, No. 2 (2008), h. 266; Ott Puumeister \& Andreas Ventsel, "Biopolitics Meets Biosemiotics: The Semiotic Thresholds of Anti-Aging Interventions" dalam Theory, Culture \& Society, Vol. 35, No. 1 (2018), h. 118. h. 33-39.

${ }_{11}$ Thomas Lemke, Biopolitics: An Advanced Introduction (New York: New York University Press, 2001), 
kepentingan ekonomi. Sementara bentuk yang kedua, yakni kontrol aturan (regulasi) terhadap populasi diwujudkan dalam bentuk perlindungan dan pengamanan populasi (sebagai entitas biologi) dari resiko dan bahaya internal dengan klasifikasi seperti tingkat kelahiran-kematian, status kesehatan dan tingkat harapan hidup. ${ }^{12}$

Giorgio Agamben memberikan gambaran mengenai relasi kekuasaan, pengetahuan, politik hukum dan masyarakat yang menurutnya sangat erat berkaitan. Di sisi lain Michael Hardt dan Antonio Negri, juga melihat hal yang sama, yakni adanya kekuasaan transendental dari kapitalisme global yang mereduksi kedaulatan negara modern khususnya yang terkait dengan kebijakan kesehatan. Dalam hal ini, bisa terlihat bahwa konsep biopolitik sangat terkait dengan power (kekuasaan), knowledge (pengetahuan), life (kehidupan), body (tubuh) dan apparatus (teknologi pengontrol). Kelima aspek tersebut saling berkaitan dan saling mendukung dalam biopolitik. ${ }^{13}$

Bagi Faucault kekuasaan itu menyebar ke segala lini tanpa bisa di segmentasi, ia menjadi bagian dan meresap dalam relasi sosial dan berbentuk bukan hanya antara pemerintah (presiden, perdana menteri, raja) kepada yang diperintah (masyarakat, LSM dan Perusahaan) namun juga bisa muncul dalam relasi antara dokter-pasien, dosenmahasiswa, bahkan dalam hubungan suami-istri. ${ }^{14}$ Kekuasaan dalam pengertian tersebut, tidak bisa dimonopoli karena beroperasi dalam segala lini kehidupan masyarakat yang kompleks. ${ }^{15}$ Eksistensi biologis masyarakat merupakan target utama dari strategi kontrol dan intervensi politik yang menganggap manusia sebagai spesies. Hal ini dilakukan agar masyarakat lebih 'produktif' secara ekonomi dan 'patuh' secara politik. $^{16}$

Masyarakat diatur dalam pengarusutamaan wacana norma dan ideologi dimana norma dan ideologi cenderung lebih ditaati daripada hukum. Norma tersebut kemudian

12 Rizma Afian Azhim \& Gema Ramadhan, "Kebebasan Berserikat dan Keamanan Negara: Analisa Biopolitik Transformasi Kebebasan Serikat Buruh di Indonesia" dalam Jurnal Keamanan Nasional, Vol. IV, No. 1 (2018), h. 20-24.

13 Michael Hardt \& Antonio Negri, Empire (London: Harvard University Press, 2000), h. 20-40; Giorgio Agamben, Homo Sacer: Sovereign Power and Bare Life (California: Stanford University Press, 1995), h. 20112.

${ }^{14}$ D. Jupriono, Yudhi Hari Wibowo \& Linusia Marsi, “Teks Berita Konflik Pekerja PT Freeport Indonesia: Analisis Wacana Kritis Foucault” dalam Parafrase, Vol. 13, No. 1 (2013), h. 53-63.

15 Haryatmoko, "Michel Foucault dan Politik Kekuasaan: Membongkar Teknik, Mekanisme, dan Strategi Kekuasaan" dalam Materi Pelatihan Analisis Wacana Michel Foucault, UK2JT, FIB Unair, Surabaya, 1 Maret (2012).

${ }^{16}$ Stefan Elbe, “AIDS, Security, Biopolitics”, dalam International Relations, Vol 19, No. 4 (2005), h. 29. 
diterapkan dalam tatanan kesehatan modern melalui regulasi kesehatan oleh lembaga negara yang memiliki kekuasaan legal. Pada tahapan selanjutnya, kontrol terhadap individu kemudian tidak hanya pada tingkat kesadaran akan norma tersebut namun juga diimplementasikan dalam tubuh mereka sendiri. Mekanisme tersebut bekerja melalui anjuran-anjuran rasional untuk melakukan tindakan tertentu, salah satunya adalah program KB. ${ }^{17}$ Biopolitik dalam kasus ini dilaksanakan melalui regulasi kesehatan yang dilaksanakan oleh lembaga otoritas negara yang bertujuan untuk menciptakan kebaikan dan kesejahteraan bagi semua warga negara. Dengan mekanisme ini negara dapat mengontrol perilaku masyarakat sekaligus mempengaruhi tindakan apa yang akan dilakukan, sehingga masyarakat tersebut dapat mengatur diri sendiri. ${ }^{18}$

Dalam pengertian ini, biopolitik berupaya menciptakan kesehatan dan kesejahteraan bagi populasi masyarakat secara layak. Dalam Society Must Be Defended, Foucault mengilustrasikan bahwa biopolitik pada akhirnya adalah tentang 'kekuatan untuk hidup', baik hidup sebagai manusia sosial maupun 'hidup secara ekonomi'. ${ }^{19}$ Dengan demikian, dualitas biopolitik sebagai kekuatan kapiler ekspansif yang menargetkan adanya peningkatan kualitas manusia di bidang sosial sekaligus juga untuk mengelola kesejahteraan ekonomi penduduk.

Konsep biopolitik yang dikemukakan Foucault ini kembali membentangkan ingatan kita bersama kepada adagium klasik Aristoteles tentang hubungan yang melekat antara manusia dan politik, yaitu, "manusia pada dasarnya adalah binatang politik" (man is by nature a political animal). Namun, dalam pembahasan Michel Foucault, ia mampu mengurai wacana biopolitik secara lebih lengkap dari pemikiran politik tradisional Aristoteles. Foucault mampu menunjukkan hubungan yang mendalam tentang hubungan antara tubuh dan politik. Sejak abad ke-18, kekuasaan dan politik mulai mencampuri urusan populasi (tubuh manusia) dalam skala besar. Hidup manusia, termasuk objek yang dikontrol oleh kekuasaan. Sebagai produk pengetahuan dan kekuasaan, biopolitik memang pada akhirnya selalu dikaitkan dengan politik tubuh.

\footnotetext{
17 Haryatmoko, "Kekuasaan Melahirkan Anti Kekuasaan: Menelanjangi Mekanisme dan Teknik Kekuasaan Bersama Foucault” dalam Basis, No. 1-2, Tahun 51 (2002), h. 8-21.

18 Nurul Maulina, "Interaksi Pemerintah dan Masyarakat Dalam Implementasi Program Penanggulangan Gizi Buruk di Kota Surabaya: Kajian Biopolitik" dalam Jurnal Politik Muda, Vol. 2, No. 1 (2012), h. 147-157.

${ }^{19}$ Michael Foucault, Society Must Be Defended (New York: Ficador, 2003), h. 240-247.
} 
ilmu kehidupan, dan struktur pemerintahan. ${ }^{20}$

Tubuh manusia selalu bisa digunakan sebagai instrumen kekuasaan. Dalam kasus ini, tubuh manusia dilihat sebagai mekanisme disiplin dari negara. Jean Francois Bayart menyatakan bahwa kunci dari pengontrolan terhadap negara adalah dengan mengontrol rahim perempuan (ia mengistilahkannya dengan politik perut). Apa yang kini terjadi di Samarinda dan Indonesia pada umumnya adalah rahim perempuan diatur demi kepentingan dan kebijakan negara. ${ }^{21}$

Upaya untuk menurunkan angka kelahiran (Total Fertility Rate) yang masih tinggi untuk wilayah Samarinda dan Kalimantan Timur mencerminkan upaya mekanisme disiplin tersebut. Pemerintah Kota Samarinda dan Badan Kependudukan dan Keluarga Berencana Nasional (BKKBN) Provinsi Kalimantan Timur menargetkan Petugas Keluarga Berencana (PKB) dan Penyuluh Lapangan Keluarga Berencana (PLKB) untuk menurunkan angka kelahiran (TFR) yang masih berada pada angka 2,7\% berdasarkan hasil Survei Demografi dan Kesehatan Indonesia (SDKI) tahun 2017. Selain berupaya menurunkan angka kelahiran, Pemerintah juga berupaya meningkatkan jumlah angka pemakaian alat/obat kontrasepsi (Contraceptive Prevalence Rate/CPR) di Kalimantan Timur. Upaya tersebut telah berhasil dilakukan. Kalimantan Timur merupakan daerah yang penggunaan alat kontrasepsinya berhasil menyentuh angka $71,1 \%$ atau di atas angka nasional yang ditarget hanya $66,0 \%$. Perbedaan CPR antara kabupaten dan kota di seluruh Kalimantan Timur hanya mempunyai selisih margin sebesar 3,56 poin. Di mana kabupaten sekitar 72,2 dan kota capai 68,7. Kondisi ini mengindikasikan bahwa strategi pendekatan program KB di Kalimantan Timur hampir sama kuat dan tepat untuk seluruh daerah. ${ }^{22}$

Pengerahan dalam bentuk biopower/ biopolitik oleh pemerintah sebagai pemilik otoritas terlihat dari upaya untuk menurunkan angka kelahiran dan menaikan angka penggunaan alat/obat kontrasepsi. Biopower merujuk pada adanya mekanisme yang mana perangkat dasar biologis manusia menjadi objek dari strategi politik dan strategi h. 287-296.

${ }^{20}$ Jiangxia Yu \& Jingwey Liu, “The New Biopolitics” dalam Journal of Academic Ethics Vol. 7 (2009),

${ }^{21}$ Johanna Poerba, "Dewi Candraningrum: Ada Reduksi dalam Mitos Narasi Agung Ibu" dalam https://www.jurnalperempuan.org/warta-feminis/dewi-candraningrum-ada-reduksi-dalam-mitos-narasiagung-ibu diakses 28 Agustus 2020.

22 Humas Provinsi Kalimantan Timur, "Kesertaan KB Kalimantan Timur Diatas CPR Nasional" dalam https://Kalimantan Timurprov.go.id/berita/kesertaan-kb-Kalimantan Timur-diatas-cpr-nasional-2. diakses 23 Agustus 2020. 
kekuasaan. Aspek keamanan (termasuk keamanan biologis) merupakan alasan bagi lembaga negara untuk melakukan kontrol terhadap populasi. ${ }^{23}$ Atas dasar itulah. kajian biopolitik memang sangat melekat dan berkaitan dengan permasalahan biologis dan kesehatan serta pertumbuhan dan populasi penduduk. ${ }^{24}$ Biopolitik di sisi lain juga membahas tentang kehidupan masyarakat yang berubah menjadi objek politik pemerintah. Sehingga pemerintah memiliki kuasa untuk dapat mengatur masyarakat. ${ }^{25}$

Foucault juga menganalisis wacana modern tentang seksualitas di mana moral, sains, dan kekuasaan (pemerintah) saling berkaitan. Peranan lembaga politik dan medis dalam hal ini dilakukan oleh Pemerintah Kota Samarinda yang melakukan kerja sama dan koordinasi dengan BKKBN Provinsi dan Dinas Kesehatan telah berkontribusi pada dimensi seksual kehidupan individu dan sosial. Pengelolaan populasi ini akan menjadi aspek perhatian utama pemerintah di masa mendatang. ${ }^{26}$ Macey juga menyatakan bahwa rekonstruksi pergeseran kekuasaan terjadi dalam bentuk kebijakan biopolitik. ${ }^{27}$ Pada intinya, Garlick dan Neilson serta Foucault saling bersepakat bahwa populasi telah menjadi kata kunci dalam pembahasan biopolitik. ${ }^{28}$ Jadi bisa dikatakan, bahwa biopolitik merupakan sebuah upaya untuk melakukan kontrol populasi.

Keberhasilan dalam strategi pendekatan program KB di Samarinda ini salah satunya adalah peran BKKBN yang mampu melakukan advokasi dan bisa merubah pola pikir masyarakat bahwa program KB itu bermanfaat untuk mereka bukan hanya dari sisi kesehatan saja tetapi juga dari sisi ekonomi. Strategi efektif tersebut terlihat dari peningkatan keikutsertaan masyarakat dalam ber-KB yang meliputi pembinaan kesertaan ber-KB baik melalui jalur pemerintah maupun swasta. Tujuan dari keikutsertaan ini adalah peningkatan pembinaan lini lapangan guna meningkatkan

${ }^{23}$ Kevin Stenson, "Sovereignty, Biopolitics and the Local Government of Crime in Britain" dalam Theoretical Criminology, Vol. 9, No. 3 (2005), h. 265-287; Andi Amitya Dwiyanti \& M Najeri Al Syahrin, "Penerapan Developmental State Dalam Sektor Industri Kecil Menengah Di Indonesia: Studi Kasus Kabupaten Bone" dalam Journal of Islamic World and Politics, Vol.2, No. 1 (2018), h. 205-207.

24 Chandraningrum, "Kelas Filsafat Feminisme: Biopolitik Michel Foucault" dalam https://kesolo.com/kelas-filsafat-feminisme-biopolitik-michel-foucault/ diakses 15 Agustus 2020.

${ }^{25}$ Michael Foucault, 2003, Op.Cit., h. 200; Stuart J. Murray, "Affirming the Human? The Question of Biopolitics, Law, Culture and the Humanities" dalam Law, Culture and the Humanities, Vol. 12, No. 3 (2016), h. $485-495$.

${ }^{26}$ Michael Foucault, 2003, Op.Cit., h. 201.

${ }_{27}$ David Macey, "Rethinking Biopolitics, Race and Power in the Wake of Foucault" dalam Theory, Culture \& Society, Vol. 26, No. 6 (2009), h. 186.

28 Steve Garlick, "The Biopolitics of Masturbation: Masculinity, Complexity, and Security" dalam Body \& Society, Vol. 20, No. 2 (2014), h. 44; Brett Neilson, “Ageing, Experience, Biopolitics: Life’s Unfolding” dalam Body \& Society, Vol. 18, No. 3 \& 4, (2012), h. 44-71; Michael Foucault, 2003, Op.Cit., h. h. 201. 
kualitas dan kuantitas PLKB/PKB di Samarinda. ${ }^{29}$ Masyarakat Samarinda memberikan respon positif terhadap setiap kegiatan PLKB/PKB, dan masyarakat juga berharap bahwa pelaksanaan kegiatan penyuluhan dan KB gratis perlu ditingkatkan di seluruh wilayah Samarinda.

Jumlah kelahiran yang terus meningkat (bonus demografi) akan menyebabkan terjadinya over populations. Hal ini menjadi peluang dan kesempatan bagi negara untuk meningkatkan kesejahteraan dan kemajuan ekonomi. Namun dalam sisi yang berbeda, kondisi tersebut juga menyebabkan negara mempunyai kontrol dalam pengelolaan kepada masyarakat (relasi kuasa) secara ideologis. Akan terjadi perluasan wujud-wujud cengkraman negara terhadap masyarakat. ${ }^{30}$ Permasalahan over populations merupakan permasalahan krusial bagi negara. Permasalahan ini tidak hanya menyangkut tentang pengelolaan dan kontrol populasi penduduk (natalitas/mortalitas/fertilitas), namun juga terkait pengelolaan kehidupan nasional (governmentality). ${ }^{31}$ Dalam kajian tentang biopolitik, persoalan kehidupan (life) manusia ataupun bangsa termasuk sebagai persoalan politik (subpolitics) dalam rangka pengaturan populasi tatanan kehidupan bernegara (governmentality). ${ }^{32}$

Upaya pendisiplinan masyarakat yang dilakukan melalui kontrol populasi tersebut mungkin saja di masa depan akan bertransformasi menjadi lebih kompleks. Fenomena menarik terjadi ini telah nampak dalam beberapa tahun belakangan seiring dengan kemajuan teknologi. Terdapat transisi masyarakat disipliner (disciplinary society) menuju masyarakat kontrol (society of control). Penjelasan dalam kasus ini adalah pendisiplinan masyarakat tidak hanya dilakukan dalam ranah pendisiplinan norma dan ideologi namun sudah mengarah menuju teknis melalui kuasa elektronik. Kontrol kekuasaan negara dilakukan melalui mesin-mesin dan peralatan elektronik yang secara langsung mengorganisir otak (dalam sistem komunikasi, jaringan informasi) serta mengorganisir tubuh (sistem kesejahteraan dan aktivitas yang dipantau). ${ }^{33}$

\footnotetext{
${ }^{29}$ Melly Putri Amalini, "Strategi Badan Kependudukan dan Keluarga Berencana Nasional (BKKBN) dalam Meningkatkan Pengguna Program Keluarga Berencana di Kota Samarinda”. Skripsi. (Samarinda: Fisip, Universitas Mulawarman, 2019), h. 22-27.

30 Andi Faisal, "Biopolitik dan Gerakan Literasi Komunikatif Kaum Muda" dalam Journal Communication Spectrum, Vol. 8, No. 1(2018), h. 72.

31 Thomas Lemke, Op.Cit., h. 26.

32 Michel Foucault, The Birth of Biopolitics: Lectures at the College de France 1978-1979 (New York: Palgrave Macmillan, 2008), h. 12-40.

${ }^{33}$ Andi Faisal, Loc.Cit.
} 
Beberapa kebijakan pemerintah mengindikasikan fenomena ini mulai terlihat. Pembuatan Kartu Indonesia Pintar, Kartu Tani, Kartu Pra Kerja, Kartu Indonesia Sehat, BPJS, Beasiswa Bidik Misi, serta Penyesuaian kartu keluarga dan NIK dengan nomor telepon seluler merupakan beberapa contoh dari praktik biopolitik (biopower). ${ }^{34}$

Giorgio Agamben dalam Homo Sacer (1995) secara lebih komprehensif sudah memprediksi hal ini. Ia menjelaskan bahwa representasi biopolitik modern (kontemporer) cenderung mengklasifikan masyarakat menjadi dua kelompok, yakni masyarakat yang berada dalam kondisi tidak layak mendapatkan tempat dalam kehidupan bernegara (ia mengistilahkannya dengan 'zoe') serta masyarakat yang berada dalam kondisi "bios" (political existence) yakni masyarakat yang layak. Garis pemisah antara dua kelompok ini mengakibatkan hak-hak (warga) dalam suatu negara/populasi mengalami politisasi. ${ }^{35}$ Perbedaan ini akhirnya menimbulkan pemisahan antara kalangan minoritas versus mayoritas dalam berbagai bentuk, bisa dalam aliran politik (tradisional versus modern), kepercayaan (agama), ekonomi (masyarakat kaya dan masyarakat miskin) serta bisa juga dalam pendidikan (kalangan terdidik dan tidak terdidik). Pada akhirnya kondisi kutub ekstrim perbedaan antar masyarakat ini mengakibatkan konflik mudah terjadi. ${ }^{36}$

Namun pemerintah perlu menyadari bahwa kebijakan pembatasan atau kontrol populasi yang dilakukan melalui program KB juga bisa menyebabkan terjadinya efek negatif. Di beberapa negara seperti Jepang dan Korea Selatan, yang populasi masyarakatnya memiliki sedikit anak memiliki kesulitan dalam menopang populasi tenaga kerja. Tenaga kerja aktif banyak yang sudah hampir memasuki masa pensiun dan generasi selanjutnya masih belum siap untuk menggantikannya. Tenaga kerja yang menyusut tersebut mengisyaratkan bahwa akan sedikit pembayar pajak untuk negara. Negara penganut paham liberal yang bergantung pada pertumbuhan ekonomi, berada dalam kekhawatiran karena jumlah pekerja saat ini relatif kecil dalam menyokong generasi tua yang memasuki masa pensiun. Hal ini tentu, meresahkan bagi orang-orang yang cenderung menganggap keputusan melahirkan anak sebagai masalah moralitas

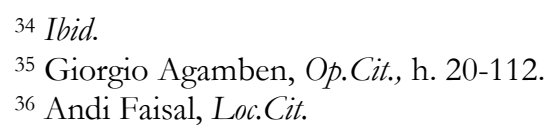


pribadi. ${ }^{37}$

Solusi bagi masalah ini yang sudah diterapkan adalah kebijakan imigrasi dan transmigrasi yang diperluas. Namun, kebijakan ini juga di sisi lain membawa efek negatif lainnya yakni menjadi sumber krisis identitas nasional, kerusuhan dan xenophobia. Hal tersebut, telah terjadi di India, Cina, Taiwan, Pakistan, dan Afghanistan. Aborsi janin perempuan, telah menghasilkan populasi dengan kira-kira 100 juta populasi laki-laki lebih banyak daripada populasi perempuan. Krisis yang terjadi, khususnya di Pakistan dan Afghanistan, laki-laki menjadi konstituen utama bagi gerakan-gerakan politik ekstremis. Dengan kata lain, kontrol populasi yang dilakukan oleh negara mengakibatkan tidak hanya efek positif namun juga efek negatif. ${ }^{38}$

\section{Keluarga Berencana: Alat Mekanisme Kontrol Populasi di Kota Samarinda}

Setelah tumbangnya rezim Orde Baru dan pemberlakuan sistem era reformasi yang menghasilkan sistem otonomi daerah. Negara tidak lagi bersifat totaliter dan sentralistik, beberapa kebijakan kenegaraan diserahkan otoritasnya kepada daerah (kabupaten/kota), termasuk juga pelaksanaan program KB. ${ }^{39}$ Kebijakan program KB yang diterapkan di Indonesia adalah metode pengendalian kelahiran yang memungkinkan pasien untuk mencegah reproduksinya. Dalam arti luas, program ini adalah upaya untuk mempertimbangkan faktor-faktor yang mempersatukan salah satu pasangan dalam mencapai kehamilan, serta upaya menangani kelebihan beban populasi penduduk di dunia. Kebijakan ini juga merupakan upaya untuk memberikan keuntungan bagi wanita dalam mengatur fertilitasnya sehingga mereka dapat ikut dalam kegiatan kemasyarakatan, dunia kerja dan keluarga. ${ }^{40}$ Dalam program KB tersebut terdapat tiga fase utama yang disasar dalam kebijakan ini, yakni pertama fase menunda dan mencegah kehamilan bagi pasangan usia subur dengan usia istri di bawah 20 tahun. Kedua, fase untuk menjarangkan kehamilan periode usia istri antara 20-30 tahun yang merupakan periode usia yang paling baik. Ketiga yaitu fase untuk menghentikan atau

\footnotetext{
${ }^{37}$ Jedediah Purdi, "The New Biopolitics" dalam https://democracyjournal. org/magazine/1/the-newbiopolitics/ diakses 23 Agustus 2020.

${ }^{38}$ Ibid.

39 Sabrur Rohim, "Argumen Program Keluarga Berencana (KB) Dalam Islam" dalam Al Abkam: Jurnal Ilmu Syari' Ab dan Hukum, Vol. 1, No. 2 (2016), h. 147-170.

${ }^{40}$ Moore Hacker, Esensial Obstetri dan Ginekologi (Jakarta: Hiprocrates, 2001), h. 225.
} 
mengakhiri kehamilan serta kesuburan. ${ }^{41}$

Di masa Orde Baru tahun 1970 sampai akhir 1990-an program KB menjadi program utama pemerintah. Negara begitu gencar menekan laju pertumbuhan penduduk dengan dalih sebagai upaya untuk mengejar kemajuan pembangunan. Atas dasar itu, negara berupaya menggenjot pertumbuhan ekonomi nasional dengan melakukan kontrol populasi penduduk. Negara berkeyakinan bahwa kemajuan ekonomi serta berlimpahnya sumber daya alam (SDA), tidak akan ada artinya jika pemerintah juga harus menanggung beban populasi yang tinggi. Menariknya dalam upaya kontrol populasi melalui program $\mathrm{KB}$ ini pemerintah tidak hanya menggunakan agen-agen operasional dari pihak kesehatan seperti dokter, bidan, Penyuluh Keluarga Berencana (PKB), paramedis, anggota PKK, dan Puskesmas saja tetapi juga mendayagunakan para tokoh masyarakat dan tokoh agama. Tokoh agama bertugas untuk mengintroduksikan, dan memberikan doktrin kepada masyarakat tentang pentingnya melakukan program KB. Bahkan, Majelis Ulama Indonesia (MUI) mengeluarkan fatwa yang mendukung program KB. ${ }^{42}$ Di berbagai negara lain, organisasi keagamaan juga peduli dengan permasalahan populasi manusia ini. Konsep biopolitik memang bisa diterapkan dalam berbagai konteks, dari biologi, agama hingga filsafat politik. ${ }^{43}$

Secara umum, pencapaian program Kependudukan Keluarga Berencana dan Pembangunan Keluarga (KKBPK) di Provinsi Kalimantan Timur dan secara khusus di Kota Samarinda telah berhasil dilakukan dengan baik karena dukungan, partisipasi dan komitmen para stakeholder pemerintahan terkait. Berdasarkan hasil evaluasi kegiatan yang disampaikan oleh Kepala Dinas Kependudukan, Pemberdayaan Perempuan dan Perlindungan Anak (DKP3A) Provinsi Kalimantan Timur, pelaksanaan program KKBPK selama semester I tahun 2019 telah berjalan lebih baik daripada sebelumnya. Pelaksanaan yang lebih baik tersebut dilihat pada adanya peningkatan penggunaan alat kontrasepsi, serta penurunan angka unmed need. Selain itu juga terdapat peningkatan jumlah Kampung KB yang hingga kini mencapai 253 Kampung KB di seluruh wilayah

\footnotetext{
${ }^{41}$ Hartanto, Keluarga Berencana dan Kontrasepsi (Jakarta: Pustaka Sinar Harapan, 2003), h. 30.

42 Kamaludiningrat, Peran dan Tantangan Orangtua dalam Mendidik. Anak Shaleh, Berakblak dan Berkaraketer di Era Globalisasi (Yogyakarta: Fapsedu DIY, 2004), h. 25.

43 Thomas Lemke, Op.Cit., h. 10-11.
} 
daerah Kalimantan Timur. ${ }^{44}$

Kota Samarinda termasuk kota yang paling tinggi tingkat pertumbuhan Kampung KB di seluruh wilayah Indonesia serta menjadi percontohan dalam pendirian Kampung KB oleh Badan Kependudukan dan Keluarga Berencana Nasional. Program nasional Kampung KB yang diselenggarakan menargetkan 1 Kampung KB per 1 Kecamatan. Tetapi, Pemerintah Kota Samarinda mampu menargetkan 1 Kampung KB per 1 Kelurahan. Pelaksanaan upaya tersebut dilaksanakan dengan mengintegrasikan program kependudukan KB-KS dan pemberdayaan perempuan. ${ }^{45}$

Dalam kasus pelaksanaan kegiatan dan sosialisasi program keluarga berencana (KB) di Kota Samarinda khususnya dalam pendirian Kampung KB tersebut Pemerintah Provinsi dan Pemerintah Kota melaksanakan prinsip "ibuisme negara" (state motherhood). Prinsip tersebut mengkarakterisasi cara-cara di mana praktik negara tersebut berupaya menyebarkan 'asas kekeluargaan'. Asas kekeluargaan ini disebarkan sampai ke pelosok desa yang masyarakatnya secara ikatan darah tidak memiliki hubungan keluarga. Tetapi melalui pendirian Kampung KB ditekankan prinsip bahwa mereka hidup harus saling menjaga satu sama lainya, layaknya sebuah keluarga.

Pemerintah juga berupaya menaturalisasi keluarga secara heteroseksual sebagai dasar esensial dari kebijakan strukturisasi negara. Tujuan akhirnya, warga negara diharapkan dapat berkontribusi pada kesejahteraan negara, dengan cara yang sama seperti anggota keluarga lainnya. Tubuh manusia, termasuk juga kelahiran anak, kemudian diharapkan produktif untuk berkontribusi secara ekonomi. Tubuh manusia yang "tidak produktif" semakin dipandang sebagai "beban" bagi negara. Negara kemudian melegitimasi pengaturan tertentu, termasuk juga kontrol populasi. Aturan ini pada gilirannya tidak hanya mengungkapkan bagaimana tubuh perempuan secara diamdiam dikurangi menjadi fungsi reproduksinya, tetapi juga memungkinkan pengaturan tertentu berdasarkan pada kapasitas tubuh untuk mencapai tujuan tertentu (ekonomi). ${ }^{46}$

Permasalahan ekonomi dianggap merupakan faktor utama dan alasan bagi

\footnotetext{
44 Sumarsono, "253 Kampung KB sudah Berdiri di Kalimantan Timur, Program KKBPK Perlu Komitmen stakeholder” dalam https://Kalimantan Timur.tribunnews.com/2019/08/08/253-kampung-kbsudah- berdiri-di-Kalimantan Timur-program-kkbpk-perlu-komitmen-stakeholder. diakses 26 Agustus 2020.

45 Linda, "Wawali Resmikan Kampung KB ke-48” dalam https://samarinda.prokal.co/read/news / 17768-wawali-resmikan-kampung-kb-ke-48.html diakses 14 Agustus 2020.

46 Dyah Pitaloka \& Yulius Hendri, "Love Under Surveillance: Indonesia's 'Medicalization' of Marriage" dalam https://www.thejakartapost.com/academia/2018/02/28/love-under-surveillance-indonesia s-medicalization-of-marriage.html diakses 14 Agustus 2020.
} 
pemerintah untuk melakukan kontrol populasi. Dalam kasus Pemerintah Kota Samarinda, peningkatan kualitas hidup itu diwujudkan melalui program Kependudukan Keluarga Berencana dan Pembangunan Keluarga (KKBPK). Dalam implementasi kegiatan tersebut, Pemerintah Kota Samarinda menargetkan terdapat 59 Kelurahan yang memiliki Kampung KB dan ditargetkan rampung pada Oktober 2019. Beberapa waktu lalu, 2 wilayah telah resmi menjadi kampung KB yang ke 47 dan 48. Dua Kampung KB tersebut adalah daerah Mangkupalas Kencana, Kelurahan Mangkupalas, Kecamatan Samarinda Seberang dan Tambangan Bedayung di Kelurahan Baqa, Kecamatan Sambutan. Dengan demikian kini hanya tersisa 11 Kampung KB lagi dari target yang dicanangkan Walikota sebanyak 59 Kampung KB di 59 Kelurahan di Kota Samarinda. ${ }^{47}$

Dalam tataran operasionalnya, Pemerintah Kota Samarinda tidak hanya menggunakan agen-agen pembangunan di bidang kesehatan seperti dokter, perawat, paramedis, bidan, PKB, Aparatur Sipil Negara, pengurus ormas dan kelompok wanita, bahkan juga para para tentara dan militer. Keterlibatan aktif Babinsa Koramil Samarinda Seberang dalam kegiatan KB yang dilaksanakan di Kelurahan Baqa dan Kelurahan Mangkupalas Samarinda Seberang sebagai contoh tentu saja, merupakan hal yang menarik. ${ }^{48}$ Tentara bertugas untuk tidak hanya mengamankan kegiatan KB tetapi juga untuk mengintroduksikan sekaligus "mengindoktrinasikan", kepada masyarakat bahwa tentara atau militer hadir untuk melindungi masyarakat. Kehadiran dan keterlibatan aktif tentara dalam kegiatan KB di Samarinda Seberang juga memberikan pemahaman kepada masyarakat bahwa program KB merupakan program yang didukung oleh seluruh elemen negara.

Upaya persuasif dan juga represif pemerintah dalam mensukseskan program kontrol populasi penduduk juga telah terjadi di China. Metode kontrol populasi manusia yang sangat terkenal diterapkan di China yaitu kebijakan One Child Policy. Kebijakan ini mendorong bagi seluruh warga China untuk hanya memiliki satu anak saja. Sehingga, jika ada keluarga yang memiliki anak lebih dari satu, maka tidak akan diakui kewarganegaraannya serta tidak dapat mengakses hak-hak yang dimiliki oleh warga negara, seperti fasilitas kesehatan dan pendidikan. Kebijakan ini terbukti sukses dalam

${ }^{47}$ Sumarsono, Loc.Cit.

48 Kodam Mulawarman, "Pelibatan Babinsa Sangat Diperlukan Dalam Program KB. Kodam Mulawarman" dalam https://www.kodam-mulawarman.mil.id/web/pelibatan-babinsa-sangat-diperlukan-dalamprogram-kb/ diakses 14 Agustus 2020. 
mencegah jumlah kelahiran di China sejak diterapkan pada tahun 1978. Meskipun demikian, kebijakan ini juga memberikan permasalahan sosial baru seperti besarnya praktek aborsi ilegal di China serta banyak warga negara China keluar dari negaranya demi menghindari kebijakan tersebut. ${ }^{49}$

Upaya untuk membujuk warga mengikuti program KB juga terlihat dari besarnya dukungan anggaran dalam menyukseskan program KB. Alokasi anggaran program kependudukan dan KB, tidak hanya bersumber dari APBD Provinsi Kalimantan Timur saja, tetapi juga bersumber dari APBD kabupaten/kota. Selain APBD Provinsi dan Kabupaten, tambahan dana juga diberikan dari anggaran nasional. Sinergi ketiga sumber anggaran ini semakin memudahkan realisasi program KB di lapangan. ${ }^{50}$ Selain dari besaran anggaran diberikan, Pemerintah juga selalu berupaya memberikan pelayanan KB gratis. Melalui Dinas Pengendalian Penduduk dan Keluarga Berencana (DPPKB) Kota Samarinda melakukan pelayanan KB gratis di Bantaran Sungai Karang Mumus (SKM) di Kelurahan Bandara Kecamatan Sungai Pinang. Pemerintah Kota Samarinda menargetkan beberapa wilayah yang dianggap rawan atau masuk dalam daerah prioritas KB gratis. Daerah tersebut antara lain daerah kumuh. padat penduduk, pra sejahtera, dan anggota KB yang pesertanya sedikit. Bagi Pemerintah Kota, pelayanan KB diberikan untuk meningkatkan kesejahteraan, menghindarkan remaja dari pernikahan dini serta pembentukan keluarga berkualitas. ${ }^{51}$

Keseluruhan upaya pemerintah baik yang dilakukan oleh Pemerintah Pusat, Pemerintah Provinsi maupun Pemerintah Kota di Samarinda terkait dengan program KB baik melalui pendirian Kampung KB, program penurunan angka lahir, peningkatan penggunaan alat/obat kontrasepsi, penggunaan instrumen militer, alokasi anggaran level pusat, provinsi dan kota serta pemberian layanan KB gratis merupakan biopolitik untuk melakukan kontrol terhadap populasi manusia (Human Population Control). Human population control merupakan sebuah praktek penanganan dalam pertumbuhan skala

${ }^{49}$ Junsen Zhang, "The Evolution of China's One-Child Policy and Its Effects on Family Outcomes” dalam Journal of Economic Perspectives, Vol. 31, No. 1 (2017), h. 141-160; Xiao-Tian Feng, Dudley Poston Jr \& Xiao-Tao Wang, "China's One-child Policy and the Changing Family" dalam Journal of Comparative Family Studies, Vol. 45, No. 1 (2014), h. 17-29.

${ }^{50}$ Bontang Prokal, "Gemakan Pentingnya Program KB di Kalimantan Timur, BKKBN Gandeng Berbagai Stakeholder” dalam https://bontang.prokal.co/read/news/17437-gemakan-pentingnya-programkb-di-Kalimantan Timur -bkkbn-gandeng-berbagai-stakeholder.html diakses 14 Agustus 2020.

51 IPKB Kalimantan Timur, "DPPKB Samarinda Lakukan Pelayanan KB Gratis" dalam https://www. Ipkb Kalimantan Timur.com/dppkb-samarinda-lakukan-pelayanan-kb-gratis.html diakses 19 Agustus 2020; SI, Staff BKKBN Kalimantan Timur, wawancara, 1 November 2019. 
populasi manusia. Human population control telah diimplementasikan untuk membatasi angka kelahiran populasi sebuah negara yang disertai dengan mandat dan kebijakan pemerintah. Kebijakan ini diambil sebagai upaya untuk merespon kemiskinan, ledakan penduduk dan lingkungan. 52

Pada awalnya, praktik kontrol populasi dilakukan menggunakan metode kontrasepsi, abstinence (penahan nafsu), aborsi, kelaparan, wabah dan peperangan. Metode ini dinilai melanggar norma dan etika hak asasi manusia. Seiring berkembangya zaman, terdapat pergeseran kebijakan di kalangan pemerintah sendiri dalam implementasi kontrol populasi. Dalam prakteknya, secara umum kontrol populasi manusia merupakan upaya untuk meningkatkan taraf hidup masyarakat dengan memberikan kesempatan lebih besar kepada individu untuk mengontrol sendiri reproduksi mereka. Tetapi tidak dapat dipungkiri masih terdapat praktik eksploitasi dalam penerapan kontrol populasi tersebut termasuk juga melalui program $\mathrm{KB}^{53}$

\section{Kesimpulan}

Gagasan biopolitik dalam beberapa tahun terakhir mulai menguat karena kesadaran kolektif masyarakat. Kesadaran ini kemudian menarik minat untuk memperluas konsep biopolitik yang awalnya hanya merupakan konsep yang terkait dengan biologi dan politik kini berkembang menjadi konsep yang melakukan kontrol populasi manusia. Negara dalam hal ini pemerintah sebagai subjek kolektif telah memaksa tubuh manusia (masyarakat) untuk kepentingan politik dan ekonomi, tidak hanya terbatas pada kepentingan kesehatan saja. Biopolitik menempatkan aspek biologis tubuh manusia dalam tatanan politik serta memandang manusia bukan hanya sebagai makhluk hidup tetapi juga merupakan subjek politik. Kehidupan manusia memberi peluang terhadap masuknya kekuasaan negara sampai pada tubuh personal (individual). Tujuan esensial dari kekuasaan negara ini adalah mengamankan stabilitas biologis populasi untuk tujuan ekonomi.

Melalui program KB yang dilaksanakan dengan berbagai level pemerintahan di Kota Samarinda, Pemerintah berupaya mendisiplinkan tubuh perempuan serta

\footnotetext{
2006), h. 30-39.

52 Lara Knudsen, Reproductive Rights in a Global Context (Tennessee: Vanderbilt University Press,

${ }^{53}$ Kevin Stenson, Loc.Cit.
} 
seksualitasnya untuk mencapai target-target politik yang didasarkan tidak hanya pada asumsi medis (kesehatan) namun juga asumsi ekonomis. Keseluruhan upaya yang dilakukan terkait dengan program KB baik melalui pendirian Kampung KB yakni 1 Kampung KB per 1 Kelurahan dan target yang dicanangkan Walikota sebanyak 59 Kampung KB di 59 Kelurahan di Kota Samarinda. Selain itu juga dilakukan upaya dan program untuk menurunkan angka kelahiran (Total Fertility Rate), peningkatan jumlah angka pemakaian alat/obat kontrasepsi (Contraceptive Prevalence Rate/CPR), kerja sama dan koordinasi dengan BKKBN Provinsi dan Dinas Kesehatan, serta peningkatan meningkatkan kualitas dan kuantitas PLKB/PKB di Kota Samarinda. Pemerintah Kota Samarinda melalui BKKBN dan Dinas Kesehatan juga melaksanakan kegiatan penyuluhan dan $\mathrm{KB}$ gratis serta melibatkan Babinsa Koramil Samarinda Seberang dalam kegiatan KB. Alokasi anggaran program kependudukan dan KB, juga tidak hanya bersumber dari APBD Provinsi Kalimantan Timur saja, tetapi juga bersumber dari APBD Kabupaten/Kota. Selain APBD Provinsi dan Kabupaten, tambahan dana juga diberikan dari anggaran nasional. Sinergi ketiga sumber anggaran ini semakin memudahkan realisasi program $\mathrm{KB}$ di lapangan.

\section{DAFTAR PUSTAKA}

Agamben, Giorgio. Homo Sacer: Sovereign Power and Bare Life. California: Stanford University Press, 1995.

Amalini, Melly Putri. “Strategi Badan Kependudukan dan Keluarga Berencana Nasional (BKKBN) dalam Meningkatkan Pengguna Program Keluarga Berencana di Kota Samarinda". Skripsi. Samarinda: Fisip, Universitas Mulawarman, 2019.

Azhim, Rizma Afian \& Gema Ramadhan. "Kebebasan Berserikat dan Keamanan Negara: Analisa Biopolitik Transformasi Kebebasan Serikat Buruh di Indonesia" dalam Jurnal Keamanan Nasional, Vol. IV, No. 1 (Mei 2018), h. 1939.

Badan Pusat Statistik. Statistik Indonesia 2017. Jakarta: BPS - Statistik Indonesia, 2017.

Creswell, John. Research Design: Qualitative, Quantitative and Mixed Methods Approaches. California: Sage Publications, 2013. 
Dillon, Michael \& Luis Lobo-Guerrero. "Biopolitics of Security in the 21st Century: An Introduction" dalam Review of International Studies, Vol. 34, No. 2 (2008), h. 265-292.

Dwiyanti, Andi Amitya \& M Najeri Al Syahrin. "Penerapan Developmental State Dalam Sektor Industri Kecil Menengah Di Indonesia: Studi Kasus Kabupaten Bone" dalam Journal of Islamic World and Politics, Vol.2, No. 1 (2018), h. 205227.

Elbe, Stefan. "AIDS, Security, Biopolitics" dalam International Relations, Vol 19, No. 4 (2005), h. 403-419.

Faisal, Andi. "Biopolitik dan Gerakan Literasi Komunikatif Kaum Muda" dalam Journal Communication Spectrum, Vol. 8, No. 1 (2018), h. 72-93.

Feng, Xiao-Tian \& Dudley Poston Jr., Xiao-Tao Wang. "China's One-child Policy and the Changing Family" dalam Journal of Comparative Family Studies, Vol. 45, No. 1 (2014), h. 17-29.

Foucault, Michel. The Birth of Biopolitics: Lectures at the College de France 19781979. New York: Palgrave Macmillan, 2008.

Garlick, Steve. "The Biopolitics of Masturbation: Masculinity, Complexity, and Security" dalam Body \& Society, Vol. 20, No. 2 (2014), h. 44-67.

Hacker, Moore. Esensial Obstetri dan Ginekologi. Jakarta: Hiprocrates, 2001.

Hardt, Michael \& Antonio Negri. Empire. London: Harvard University Press, 2000.

Hartanto. Keluarga Berencana dan Kontrasepsi. Jakarta: Pustaka Sinar Harapan, 2003..

Haryatmoko. "Kekuasaan Melahirkan Anti Kekuasaan: Menelanjangi Mekanisme dan Teknik Kekuasaan Bersama Foucault" dalam Basis, No. 1-2, Tahun 51 (2002), h. $8-21$.

--------. "Michel Foucault dan Politik Kekuasaan: Membongkar Teknik, Mekanisme, dan Strategi Kekuasaan" dalam Materi Pelatihan Analisis Wacana Michel Foucault, UK2JT, FIB Unair, Surabaya, 1 Maret (2012).

Idrus, Muhammad. Metode Penelitian Ilmu Sosial. Yogyakarta: Erlangga, 2009.

Jupriono, D. \& Yudhi Hari Wibowo, Linusia Marsi. "Teks Berita Konflik Pekerja PT Freeport Indonesia: Analisis Wacana Kritis Foucault" dalam Parafrase, Vol. 13, No. 1 (2013), h. 53-63.

Kamaludiningrat. Peran dan Tantangan Orangtua dalam Mendidik Anak Shaleh, Berakhlak dan Berkarakter di Era Globalisasi. Yogyakarta: Fapsedu DIY, 2004. 
Knudsen, Lara. Reproductive Rights in a Global Context. Tennessee: Vanderbilt University Press, 2006.

Lemke, Thomas. Biopolitics: An Advanced Introduction. New York: New York University Press, 2001.

Macey, David. "Rethinking Biopolitics, Race and Power in the Wake of Foucault" dalam Theory, Culture \& Society, Vol. 26, No. 6 (2009), h. 186-205.

Maulina, Nurul. "Interaksi Pemerintah dan Masyarakat Dalam Implementasi Program Penanggulangan Gizi Buruk di Kota Surabaya: Kajian Biopolitik" dalam Jurnal Politik Muda, Vol. 2, No. 1 (2012), h. 147-157.

Michael Foucault. Society Must Be Defended. New York: Ficador, 2003.

Murray, Stuart J. "Affirming the Human? The Question of Biopolitics, Law, Culture and the Humanities" dalam Law, Culture and the Humanities, Vol. 12, No. 3 (2016), h. 485-495.

Neilson, Brett. “Ageing, Experience, Biopolitics: Life's Unfolding” dalam Body \& Society, Vol. 18, No. 3-4, (2012), h. 44-71.

Nilsson, Jacob \& Sven-Olov Wallenstein (ed.). Foucault, Biopolitics and Governmentality. Stockholm: Huddinge, 2013.

Povinelly, Elizabeth \& Mathew Coleman, Kathryn Yusoff. "An Interview with Elizabeth Povinelli: Geontopower, Biopolitics and the Anthropocene" dalam Theory Culture \& Society, Vol. 34, No. 2-3 (2017), h. 169-185.

Puumeister, Ott \& Andreas Ventsel. "Biopolitics Meets Biosemiotics: The Semiotic Thresholds of Anti-Aging Interventions" dalam Theory, Culture \& Society, Vol. 35, No. 1 (2018), h. 117-139.

Rohim, Sabrur. "Argumen Program Keluarga Berencana (KB) Dalam Islam" dalam $A l$ Ahkam: Jurnal Ilmu Syari'Ah dan Hukum, Vol. 1, No. 2 (2016), h. 147-170.

Schinkel, Willem. "From Zoepolitics to Biopolitics: Citizenship and the Construction of Society" dalam European Journal of Social Theory, Vol. 13, No. 2 (2010), h. $155-172$.

Stenson, Kevin. "Sovereignty, Biopolitics and the Local Government of Crime in Britain" dalam Theoretical Criminology, Vol. 9, No. 3 (2005), h. 265-287.

Yu, Jiangxia \& Jingwey Liu. "The New Biopolitics" dalam Journal of Academic Ethics, Vol. 7 (2009), h. 287-296. 
Zhang, Junsen. "The Evolution of China's One-Child Policy and Its Effects on Family Outcomes" dalam Journal of Economic Perspectives, Vol. 31, No. 1 (2017), h. 141-160.

\section{Website}

Badan Pusat Statistik Kota Samarinda. "Jumlah Penduduk dan Laju Pertumbuhan Penduduk Menurut Kecamatan di Kota Samarinda 2010-2015" dalam https://samarindakota.bps.go.id/statictable/2016/10/19/13/jumlah-penduduk-danlajupertumbuhan-penduduk-menurut-kecamatan-di-kota-samarinda-2010-2014dan-2015.html. diakses 11 Agustus 2020.

Bontang Prokal. "Gemakan Pentingnya Program KB di Kalimantan Timur, BKKBN Gandeng Berbagai Stakeholder" dalam https://bontang.prokal.co/read /news/17437-gemakan-pentingnya-program-kb-di-Kalimantan Timur-bkkbngandeng-berbagai-stakeholde r.html diakses 14 Agustus 2020.

Chandraningrum. "Kelas Filsafat Feminisme: Biopolitik Michel Foucault" dalam https://kesolo.com/kelas-filsafat-feminisme-biopolitik-michel-foucault/ diakses 15 Agustus 2020.

Humas Provinsi Kalimantan Timur. "Kesertaan KB Kalimantan Timur Diatas CPR Nasional" dalam https://Kalimantan Timurprov.go.id/berita/kesertaan-kbKalimantan Timur-diatas-cpr-nasional-2. diakses 23 Agustus 2020.

IPKB Kalimantan Timur. "DPPKB Samarinda Lakukan Pelayanan KB Gratis" dalam https://www. ipkbKalimantan Timur.com/dppkb-samarinda-lakukan-pelayanankb-gratis.html diakses 19 Agustus 2020.

Linda. "Wawali Resmikan Kampung KB ke-48" dalam https://samarinda.prokal. co/read/news /17768-wawali-resmikan-kampung-kb-ke-48.html diakses 14 Agustus 2020.

Mulawarman, Kodam. "Pelibatan Babinsa Sangat Diperlukan Dalam Program KB. Kodam Mulawarman" dalam https://www.kodam-mulawarman.mil.id/web/ pelibatan-babinsa-sangat-diperlukan-dalam-program-kb/ diakses 14 Agustus 2020.

Pitaloka, Dyah \& Yulius Hendri. "Love Under Surveillance: Indonesia's 'Medicalization' of Marriage" dalam https://www.thejakartapost.com/academia /2018/02/28/love-under-surveillance-indonesias-medicalization-of-marriage. html diakses 14 Agustus 2020.

Poerba, Johanna. "Dewi Candraningrum: Ada Reduksi dalam Mitos Narasi Agung Ibu" dalam https://www.jurnalperempuan.org/warta-feminis/dewi-candraningrumada-reduksi-dalam-mitos-narasi-agung-ibu diakses 28 Agustus 2020. 
Purdi, Jedediah. "The New Biopolitics" dalam https://democracyjournal. org/magazine /1/the-new-biopolitics/ diakses 23 Agustus 2020.

Sumarsono. "253 Kampung KB sudah Berdiri di Kalimantan Timur, Program KKBPK Perlu Komitmen stakeholder" dalam https://Kalimantan Timur.tribunnews. com/2019/08/08/253-kampung-kb-sudah-berdiri-di-Kalimantan Timur-programkkbpk-perlu-komitmen-stakehol der. diakses 26 Agustus 2020.

United Nations. "World Population Projected to Reach 9.7 billion by 2050" dalam http://www.un.org/en/development/desa/news/population/2015-report.html diakses 19 Agustus 2020.

\section{Wawancara}

SI, Staff BKKBN Kalimantan Timur, wawancara, 1 November 2019. 


\section{PEDOMAN PENULISAN JURNAL POLITIK PROFETIK}

Sebelum penulis mengirim naskah ke redaksi Jurnal Politik Profetik (JPP), sebaiknya mengikuti ketentuan dan sistematika penulisan di bawah ini:

\section{A. Pedoman Untuk Artikel}

1. Topik yang dipublikasikan oleh Jurnal Politik Profetik berhubungan dengan Politik Islam, Demokrasi, Pemilu dan Partai Politik, Gerakan Sosial Islam dan Politik Lokal.

2. Masalah yang diangkat sebaiknya kasus 5 tahun terakhir (jika penelitian lapangan) yang memuat unsur kebaruan.

3. Naskah belum pernah dipublikasikan.

4. Sumber rujukan minimal $75 \%$ berasal dari jurnal ilmiah/buku terbitan lima tahun terakhir. Disarankan mengutip satu sampai tiga artikel dari terbitan Jurnal Politik Profetik.

5. Naskah yang dikirim ke JPP tidak dibenarkan dikirim ke penerbit lain untuk dipublikasikan sebelum ada keputusan dari pengelola JPP, dimuat atau tidaknya.

6. Panjang artikel sekitar 6000-8000 kata, namun naskah yang lebih panjang akan dipertimbangkan.

7. Naskah harus diserahkan untuk dipertimbangkan melalui website Jurnal Politik Profetik pada link http://journal.uin-alauddin.ac.id/index.php/ipp/about/submissions\#online $\underline{\text { Submissions }}$

8. Naskah diketik dengan komputer menggunakan Microsoft Word, di atas kertas ukuran 21 cm x 29,7 cm (A4), spasi 1,5, huruf Times New Roman dan font size 12 pt..

9. Penulis harus bersedia untuk merevisi naskah berdasarkan masukan dari Editor dan Mitra Bestari.

10. Redaksi berhak menolak naskah yang tidak memenuhi kriteria/persyaratan teknis, mengadakan perubahan susunan naskah, memperbaiki bahasa dan berkonsultasi dengan penulis sebelum naskah dimuat.

11. Sistematika Penulisan:

\section{a. Judul Artikel}

Judul artikel harus padat, jelas dan tanpa singkatan. Jumlah maksimal 16 kata.

\section{b. Nama Penulis}

Cukup nama penulis tanpa menyertakan gelar

\section{c. Profesi/Institusi dan Email Penulis}

d. Abstrak 
Abstrak berisikan tentang: tujuan dan manfaat mansukrip ini, metodologi penelitian, hasil penelitian, dan kesimpulan. Pastikan kesemuanya itu dibuat dengan sepadat dan sejelasjelasnya. Abstrak menggunakan Bahasa Indonesia dengan jumlah kata kisaran 150-250 kata.

\section{e. Kata Kunci}

Kata kunci merefleksikan ide pokok dari naskah. Kata kunci memuat maksimal 5 kata kunci.

\section{f. Abstract}

\section{g. Keywords}

h. Pendahuluan

Pendahulan harus menggambarkan dengan jelas latar belakang masalah dan memuat pertanyaan apa yang akan dijawab dalam pembahasan. Bagian ini penulis mesti memberi argumen tentang pentingnya penelitian dilakukan. Pengutipan setiap karya tulis orang lain harus menggunakan Catatan Kaki/Footnote (Lihat Gaya Selingkung JPP). Istilah-istilah asing dicetak miring (italic).

\section{i. Tinjauan Pustaka/Literature Review}

Pada bagian ini semaksimal mungkin berisi uraian sistematis tentang informasi hasil-hasil penelitian yang pernah dilakukan oleh peneliti sebelumnya yang relevan dengan penelitian yang dilakukan. Bagian ini memuat kelebihan dan kelemahan pada penelitian terdahulu yang dapat dijadikan argumen bahwa penelitian yang dikerjakan ini bersifat menyempurnakan atau mengembangkan penelitian terdahulu. Di sini perlu juga mempertegas kebaruan dari penelitian penulis.

\section{j. Tinjauan Teori}

Bagian ini juga memuat landasan teori berupa rangkuman teori-teori dari pustaka yang mendukung penelitian, serta memuat penjelasan tentang konsep dan prinsip dasar yang diperlukan untuk pemecahan permasalahan. Landasan teori berbentuk uraian kualitatif, model matematis, atau tools yang langsung berkaitan dengan permasalahan yang diteliti. Bagian ini, penulis boleh tidak menuliskan Subbab "Tinjauan Teori”, namun langsung menuliskan subbab nama teori dan penjelasannya.

\section{k. Metode Penelitian}

Bagian ini memaparkan metode penelitian yang akan digunakan, di antaranya desain dan pendekatan penelitian, teknik pengambilan dan analisis data.

\section{Hasil dan Pembahasan}

Pada bagian ini, hasil penelitian dijelaskan secara komprehensif (singkat, padat dan jelas). Jika terdapat tabel dan gambar, atau figur-figur lainnya yang ada pada manuskrip, semuanya diletakkan simetris di tengah (seimbang antara kiri dan kanan). Bagian ini, 
penulis boleh tidak menuliskan Subbab "Hasil dan Pembahasan", namun langsung pada subbab inti persoalan yang sedang dibicarakan.

\section{m. Kesimpulan}

Kesimpulan menyesuaikan dengan apa yang diharapkan pada bagian pendahuluan di atas. Bagian ini dibuat dengan sesingkat dan sejelas mungkin.

\section{n. Daftar Pustaka}

Sumber rujukan minimal $75 \%$ berasal dari jurnal ilmiah/buku terbitan lima tahun terakhir. Disarankan mengutip satu sampai tiga artikel dari terbitan Jurnal Politik Profetik.

\section{B. Pedoman Untuk Ulasan Buku}

1. Harap sertakan di awal ulasan: Sampul Buku, Nama Penulis, Judul, Tempat, Penerbit, Tahun, Cetakan, Jumlah halaman, ISBN. Misalnya:

75 Syarifuddin Jurdi. Muhammadiyah dalam Dinamika Politik Indonesia 1966-2006. Yogyakarta: Pustaka Pelajar, 2010. Cetakan: I. Halaman: xxxviii+520. ISBN: 9786028479943.

2. Buku yang diulas merupakan buku terbitan 2 tahun terakhir.

3. Ulasan ditulis menggunakan Bahasa Indonesia atau Bahasa Inggris.

4. Naskah diketik dengan komputer menggunakan Microsoft Word, di atas kertas ukuran $21 \mathrm{~cm}$ x 29,7 cm (A4), spasi 1,5, huruf Times New Roman dan font size 12 pt.

5. Panjang rata-rata tulisan sekitar 2000-2500 kata.

6. Tinjauan harus dimulai dengan deskripsi singkat keseluruhan isi buku.

7. Hal-hal yang dapat dipertimbangkan dalam tubuh tinjauan meliputi:

- Kekuatan dan kelemahan buku yang diulas.

- Mengomentari gaya dan presentasi penulis.

- Apakah tujuan penulis telah terpenuhi atau tidak.

- Kesalahan (tipografi atau lainnya) dan kegunaan indeks.

- Kepada siapa buku itu berguna dan direkomendasikan.

8. Penulisan referensi mengacu pada Gaya Selingkung JPP.

9. Sistematika Penulisan:

\section{a. Judul}

Judul ulasan harus padat, jelas dan tanpa singkatan. Jumlah maksimal 10 kata.

\section{b. Identitas Buku}

Identitas buku berisi Sampul Buku, Nama Penulis, Judul, Tempat, Penerbit, Tahun, Cetakan, Jumlah halaman, ISBN. 


\section{c. Nama Pengulas}

Nama pengulas ditulis tanpa menggunakan gelar.

d. Afiliasi dan Email Pengulas

Institusi tempat pengulas bernaung serta alamat email yang dapat digunakan untuk berkorespondensi.

\section{e. Isi Ulasan}

Isi ulasan memuat tentang deskripsi singkat keseluruhan isi buku dan hal-hal yang dapat dipertimbangkan dalam tubuh tinjauan. Misalnya kekuatan dan kelemahan buku yang diulas, mengomentari gaya dan presentasi penulis, apakah tujuan penulis telah terpenuhi atau tidak, kesalahan (tipografi atau lainnya) dan kegunaan indeks serta kepada siapa buku itu berguna dan direkomendasikan.

\section{f. Daftar Pustaka}

Jika menggunakan sumber rujukan, maka pengutipan mengikuti Gaya Selingkung JPP. 


\section{GAYA SELINGKUNG JURNAL POLITIK PROFETIK}

\section{Footnote:}

\section{BUKU}

${ }^{1}$ David Jarry \& Julia Jarry, Collin Dictionary of Sociologi (Glasgow :Harper Collins Publishers, 1991), h. 188.

\section{Bibliography:}

Jarry, David \& Julia Jarry. Collin Dictionary of Sociologi. Glasgow :Harper Collins Publishers, 1991.

\section{Footnote:}

\section{ARTIKEL DALAM BUKU}

${ }^{1}$ Tom B. Bottomore, "Kelas Elite dan Masyarakat" dalam Sartono Kartodirdjo (eds.), Kepemimpinan dalam Dimensi Sosial (Jakarta: LP3ES, 1990), h. 24.

\section{Bibliography:}

Bottomore, Tom B. "Kelas Elite dan Masyarakat" dalam Sartono Kartodirdjo (eds.). Kepemimpinan dalam Dimensi Sosial. Jakarta: LP3ES, 1990.

\section{Footnote:}

\section{ARTIKEL DALAM JURNAL}

${ }^{1}$ Thandike Mkandawire, "Good Governance: The Itinerary of an Idea" dalam Development in Practice, Vol. 17, No. 5 (2007), h. 679.

\section{Bibliography:}

Mkandawire, Thandike. "Good Governance: The Itinerary of an Idea" dalam Development in Practice, Vol. 17, No. 5 (2007), h. 679-681.

\section{Footnote:}

\section{ARTIKEL PADA MEDIA MASSA}

${ }^{1}$ Masdar F. Mas’udi, "Hubungan Agama dan Negara” dalam Kompas, 7 Agustus 2002.

\section{Bibliography:}

Mas'udi, Masdar F. "Hubungan Agama dan Negara” dalam Kompas, 7 Agustus 2002.

\section{Footnote:}

\section{ARTIKEL DARI INTERNET}

${ }^{1}$ Noer Fauzi Rachman, "Master Plan Percepatan dan Perluasan Krisis Sosial-Ekologis Indonesia" dalam http://www.aman.or.id/wp-content/uploads/2014/06/Rachman-2014-MP3EIAMAN1.pdf diakses 31 Mei 2018.

\section{Bibliography:}

Rachman, Noer Fauzi. "Master Plan Percepatan dan Perluasan Krisis Sosial-Ekologis Indonesia" dalam http://www.aman.or.id/wp-content/uploads/2014/06/Rachman-2014-MP3EI-AMAN1. pdf / diakses 31 Mei 2017. 


\section{Footnote:}

\section{ARTIKEL PROSIDING}

${ }^{1}$ Noorhaidi Hasan, "Memahami Radikalisme Islam" dalam Paper Workshop Membangun Kesadaran dan Strategi dalam Menghadapi Gerakan Radikalisasi Agama, Depok, 19 Desember (2011).

\section{Bibliography:}

Hasan, Noorhaidi. "Memahami Radikalisme Islam" dalam Paper Workshop Membangun Kesadaran dan Strategi dalam Menghadapi Gerakan Radikalisasi Agama, Depok, 19 Desember (2011).

\section{Footnote:}

\section{SKRIPSI, TESIS, DISERTASI}

${ }^{1}$ Jumrah, "Politik Dinasti dan Monopoli Kekuasaan". Skripsi. (Makassar: Fak. Ushuluddin, Filsafat dan Politik UIN Alauddin, 2016), h. 10.

\section{Bibliography:}

Jumrah. "Politik Dinasti dan Monopoli Kekuasaan". Skripsi. Makassar: Fak. Ushuluddin, Filsafat dan Politik UIN Alauddin, 2016.

\section{Footnote:}

\section{DOKUMEN RESMI}

${ }^{1}$ Mahkamah Konstitusi RI, "Putusan Nomor 14/PUU-XI/2013 Tentang Pengujian UndangUndang Nomor 42 Tahun 2008 Tentang PemilihanUmum Presiden Dan Wakil Presiden Terhadap Undang-Undang Dasar Negara Republik Indonesia Tahun 1945" dalam https://www.bphn.go.id/data/documents ～/7.7._perkara_nomor_14-puu-2013_23_jan_2014_ pemilu_presiden_(.pdf diakses 1 Juli 2019.

\section{Bibliography:}

Mahkamah Konstitusi RI. "Putusan Nomor 14/PUU-XI/2013 Tentang Pengujian UndangUndang Nomor 42 Tahun 2008 Tentang PemilihanUmum Presiden Dan Wakil Presiden Terhadap Undang-Undang Dasar Negara Republik Indonesia Tahun 1945" dalam https://www.bphn.go.id/data/documents ／7.7._perkara_nomor_14-puu-2013_23_jan_2014_ pemilu_presiden_(.pdf diakses 1 Juli 2019.

\section{Footnote:}

\section{WAWANCARA}

${ }^{1}$ Karaeng Tutu, Kepala Desa Bontoa, wawancara, 10 Juli 2019.

\section{Bibliography:}

Karaeng Tutu, Kepala Desa Bontoa, wawancara, 10 Juli 2019. 


\section{Ibid}

\section{Contoh}

${ }^{1}$ David Jarry \& Julia Jarry, Collin Dictionary of Sociologi (Glasgow :Harper Collins Publishers, 1991), h. 188.

${ }^{2}$ Ibid.

${ }^{3}$ Ibid., h. 193.

Penjelasan contoh

- Menggunakan Ibid karena merujuk kepada catatan kaki di atasnya tanpa diselingi catatan kaki lainnya.

- ${ }^{2}$ Ibid. berarti pengarang, judul, dan halaman sama persis dengan catatan kaki yang di atasnya.

- ${ }^{3}$ Ibid., h. 193. berarti pengarang dan judul sama persis dengan catatan kaki yang di atasnya, hanya berbeda halaman. Halaman sebelumnya 188 dan yang dikutip terakhir halaman 193.

\section{Op.Cit.}

\section{Contoh}

${ }^{1}$ David Jarry \& Julia Jarry, Collin Dictionary of Sociologi (Glasgow :Harper Collins Publishers, 1991), h. 188.

'Thandike Mkandawire, "Good Governance: The Itinerary of an Idea" dalam Development in Practice, Vol. 17, No 4/5 (2007), h. 679.

${ }^{3}$ David Jarry \& Julia Jarry, Op.Cit., h. 193.

Penjelasan contoh

- Menggunakan Op. Cit. karena sebelumnya telah diselingi oleh catatan kaki lain, yaitu: ${ }^{2}$ Thandike Mkawndawire.

- Penggunaan ${ }^{3}$ David Jarry \& Julia Jarry, Op. Cit., h. 193. berarti pengarang (David Jarry \& Julia Jarry) dan judulnya (Collin Dictionary of Sociologi) sama, hanya saja halamannya berbeda dengan catatan kaki yang pertama. Halaman sebelumnya 188 dan yang dikutip terakhir halaman 193.

\section{Loc.Cit.}

Contoh

${ }^{1}$ David Jarry \& Julia Jarry, Collin Dictionary of Sociologi (Glasgow :Harper Collins Publishers, 1991), h. 188.

${ }^{2}$ Thandike Mkandawire, "Good Governance: The Itinerary of an Idea" dalam Development in Practice, Vol. 17, No 4/5 (2007), h. 679.

${ }^{3}$ David Jarry \& Julia Jarry, Loc.Cit.

Penjelasan contoh

- Menggunakan Loc. Cit. karena sebelumnya telah diselingi oleh catatan kaki lain, yaitu: ${ }^{2}$ Thandike Mkawndawire.

- Penggunaan ${ }^{3}$ David Jarry \& Julia Jarry, Loc.Cit. berarti pengarang, judul, dan halamannya (h. 188) sama. 